\section{B A Institute of \\ YK Business Administration \\ $\pi$ \\ Karachi \\ Leadership and Ideas for Tomorrow}

Business Review

Volume 4 Issue 2 July-December 2009

7-1-2009

\title{
Role of positive experiences in teachers' reflective engagement: A case study of three Individual teachers
}

Zeenat Ismail

Institute of Business Administration, Karachi, Pakistan

Rabail Qayyum

Institute of Business Administration, Karachi, Pakistan

Follow this and additional works at: https://ir.iba.edu.pk/businessreview

Part of the Educational Leadership Commons, and the Teacher Education and Professional Development Commons

\section{(c) (1)}

This work is licensed under a Creative Commons Attribution 4.0 International License.

\section{Recommended Citation}

Ismail, Z., \& Qayyum, R. (2009). Role of positive experiences in teachers' reflective engagement: A case study of three Individual teachers. Business Review, 4(2), 139-146. Retrieved from https://doi.org/ 10.54784/1990-6587.1337

This article is brought to you by iRepository for open access under the Creative Commons Attribution 4.0 License and is available at https://ir.iba.edu.pk/businessreview/vol4/iss2/11. For more information, please contact irepository@iba.edu.pk. 


\title{
Case Study
}

\section{Role of Positive Experiences in Teachers' Reflective Engagement: A Case Study of Three Individual Teachers}

\author{
Zeenat Ismail and Rabail Qayyum \\ Institute of Business Administration, Karachi, Pakistan
}

\begin{abstract}
This small-scale exploratory study examined how positive experiences influence teachers' reflective engagement. Previous research suggests that positive emotions signal personal well-being, influence further learning and lead to an increase in thinking. However, there is a need to further investigate the role of positive emotions in the realm of teachers' reflective engagement. There are very few researches that investigate how positive experiences affect teachers' perceptions of their teaching practices and their functioning. Three teachers' reflections focussing on positive experiences were qualitatively analysed to explore instances of positive emotions. The results indicate that positive emotions reaffirm self-concepts of teaching, banish negative feelings, and encourage high work engagement and deeper understanding among the teachers. The findings shed light on the role of positive emotions in positive psychology and also hold implications for methods of writing reflections in teacher education.
\end{abstract}

Keywords: Positive experiences, positive emotions, reflective engagement, positive psychology, teacher education.

\section{INTRODUCTION}

Positive psychology is the scientific study of "optimal human functioning... it is about understanding the wellsprings, processes and mechanisms that lead to desirable outcomes" (Linley, Joseph, Harrington \& Wood, 2006, pp. 5; in Coetzee \& Viviers, 2007). Research suggests that our emotions, both positive and negative, affect the way we behave (Janssen, de Hullu \& Tigelaar, 2008).

Fredrickson (2001) has developed the broaden-and-build theory of positive emotions to explain how positive affective experiences contribute to personal growth. The theory posits that positive emotions are "vehicles of individual growth" (pp. 224) and have "the ability to broaden people's thought-action repertoires and build their enduring personal resources, ranging from physical and intellectual resources to social and psychological resources" (pp. 219). It also suggests that negative emotions such as anxiety or anger narrow peoples' momentary thought-action repertoire, so that they are ready to act in a particular self-protective way. Moreover, the theory also sheds light on the enduring effects of positive emotions saying that "positive emotions, although fleeting, also have more long-lasting consequences" (pp. 224). 
Positive emotions "signal personal well-being, influence further learning and lead to an increase in thinking whereas negative emotions lead to a narrowing of the mind and a reduced problem-solving ability" (Fredrickson, 2002; Isen, 1987; in Janssen, de Hullu \& Tigelaar, 2008, pp. 118). Research also suggests that positive emotions enhance problem solving (Chuang, 2007). "Positive affect appears to promote more connection and integration of stimuli. Subjects induced to be in good moods generate a broader range of associations with common words, recall longer lists of words that are related to one another, and are more likely to solve problems that require seeing a broader set of potential relationships among the elements composing an issue" (Isen \& Daubman, 1984; Isen et al, 1985; Isen et al, 1987; in Staw, Sutton \& Pelled, 1994, pp. 54).

In the light of these theories, the present study was undertaken to investigate how positive emotions influence reflective engagement of teachers. Reflective engagement "involves a deliberate and intentional act of interrupting, or suspending, one's teaching practices to interrogate or inquire into them systematically and to heighten one's conscious awareness of one's practices and of one's students and then using that consciousness to redirect one's practice and actually acting to change" (Lyons, 2006, pp. 166). Researchers have argued that educational reformers who pay too little attention to the emotions of teaching actually ignore the foundation of teaching (Hargreaves, 1997; van den Berg, 2002). Sutton and Wheatley (2003) concluded that there is "surprisingly little recent research about the emotional aspects of teachers' lives" (pp. 327). Hence the importance of studying emotions of teachers cannot be over-emphasised.

Janssen, de Hullu \& Tigelaar (2008) carried out a contrastive analysis of reflections on positive and negative teaching experiences and found that positive experiences lead to more innovative resolutions, a higher motivation to implement these resolutions and more positive emotions. Since the present study borrows the framework for data analysis from their study, a brief overview of its methodology is presented in the following paragraphs.

Sixteen student-teachers interviewed each other in dyads using worksheets with questions and taking turns being interviewer and interviewee. Each student reflected on two problematic and two positive teaching experiences, all of which concerned the way pupils dealt with the content of the lesson. After formulating their resolutions for each experience, students were asked to rate their emotions with either + (present) or - (absent) based on a list of emotions taken from personality research based on valuation theory (Hermans \& Hermans-Janssen, 1995). Subsequently, after putting together all their resolutions, the students were asked to indicate their motivation for implementing these resolutions. Furthermore, students were requested to prioritize their resolutions in the order of which they were actually motivated to implement them in a classroom situation. These resolutions were categorized according to their content using a cyclical process of categorization (cf. Straus, 1987), generating a system of categories covering most of the resolutions. The initial analysis was performed independently by the first 
and second authors, and the labelling was compared. When categorizations did not match, these were discussed. In all matters, agreement could easily be reached. The few resolutions, which we were not able to fit into a category, were labelled as a separate category 'other'.

The researchers found that positive experiences led to high motivation. The reason for this, researchers suggest, is that when student-teachers reflect on positive experiences, they discover things that they both can do and which they value. On the other hand, when they are reflecting on problematic experiences they are reflecting upon situations they don't want to happen again and they can't do well. This makes it difficult for them to envisage a decision, which allows them to achieve what they want. This causes them to turn to a tried-and-tested or "conservative" approach which avoids the difficult situation, but probably does not allow them to achieve their goals.

The researchers also found that reflecting on positive experiences leads to positive emotions: "Emotions... derive from the relationship between person's wants and belief" (pp. 124). Positive emotions occur when a person believes that a want is, or is going to be, satisfied. Negative emotions occur when a person believes that a want is, or is going to be, frustrated. Reflecting on success focuses on what the student teacher can do and wants to do, which leads to positive feelings. Reflecting on their problems focusses on what the student teacher cannot do (well) and what he or she does not want, leading to negative emotions.

Since positive emotions seem to have such an effect, the present study was undertaken to see how positive emotions affect teacher's reflective engagement. "Teachers make constant decisions in their classrooms, and their beliefs, attitudes, and priorities provide a framework for these decisions" (Rimm-Kaufman \& Sawyer, 2004, pp. 322). Other researchers note that "the beliefs teachers hold influence their perceptions and judgements, which, in turn, affect their behaviour in classrooms" (Pajares, 1992, pp. 307; in Kane, Sandretto \& Heath, 2002, pp. 204). Therefore, there is a need to increase research knowledge within this framework and further investigate how positive experiences affect teachers' reflective engagement. Given the identified gap in research knowledge, this research has the potential to provide a better theoretical and practical understanding of the role of positive psychology in reflective engagement.

\section{RESEARCH QUESTION}

Q. How positive emotions affect teachers' reflective engagement? 


\section{METHODOLOGY}

\section{Participants}

Three female English language teachers T1, T2 and T3 teaching in a public sector university in Karachi were selected for the study. T1 had no prior experience of teaching, whereas T2 had previously taught A-levels students in a school for a year. T3 was the most experienced of the three and had taught for four years at university level. T1 and T2 taught the same course, which focused on building general fluency skills in English language. T3 taught a more advanced-level course, focussing on academic writing skills. All the teachers wrote weekly reflections, focussing on their classroom experiences.

\section{Data Analysis}

Three samples of the teachers' reflections which focussed on positive experiences were selected for data analysis. The reflections were all written during the course of the semester. The reflections were qualitatively analysed as per the framework provided by Janssen, de Hullu \& Tigelaar (2008), generating a list of categories. However, instead of dyadic interviews, the present study employs teachers own reflections for data analysis. These self-reports, based on actual classroom experiences were likely to provide authentic account of teachers' functioning. Moreover, some researchers criticise the use of surveys, questionnaires, or other multiple-choice-type inventories to gather data about teacher conceptions and beliefs, considering them as "too constraining" and that they "often do not validly represent teachers' beliefs" (Richardson, 1996, pp. 107; in Kane, Sandretto \& Heath, 2002, pp. 197). Teachers' reflections would safeguard against such issues. Three instances of positive emotions were identified.

\section{RESULTS}

The following were the major findings of the study:

\section{Reaffirming Self-concepts Of Teaching And 'Undoing Hypothesis'}

T3 had established free-writing activity as a regular class practice. In the middle of the semester, a student got an article published in the local newspaper. T3 considered this as an instance of her activity bearing fruit. She writes:

The article uplifted my spirits (I was not really cheerful that day since I had limited time to revise the strategies) since my belief that the regular free-write activity will encourage some students to write got confirmed. 
This positive experience reaffirms T3's teaching self-concepts. It can also be interpreted as an example of undoing hypothesis, according to which, "positive emotions might correct or undo the after effects of negative emotions" (Fredrickson, 2001, pp. 221).

\section{High Work Engagement And Deeper Understanding}

Work engagement refers to "the extent to which an individual feels positive, involved and fulfilled at work" and "is negatively related to job burnout" (Howard, 2008, pp 108). T1 wrote:

This was probably the best week I've had in terms of satisfaction about the student learning outcomes. From all three classes, T2 \& I came out happy and satisfied knowing we had achieved the aims of the classes. I feel out of this world when a class goes really well; I'm kind of over-excited at times but just can't help wanting to dance around and celebrate the success. And, I'm sure now that it's all because of proper planning and that too in the right direction.

In this instance, the positive experience leads $\mathrm{T} 1$ to a deeper understanding of the pedagogical practice and a potentially crucial discovery for future. Such discoveries are essential to a teacher's own professional understanding. This belief may have a longlasting effect. Moreover, T1's reflections also suggest that she experiences high work engagement as a result of this positive experience.

In another instance T1 wrote:

One of my students who had started coming on time after a lot of motivation stuff I did looked really tired on Friday, so I asked him why and he said he works at XYZ TV as a graphics designer and works from 11 to 6 in the morning. I knew that he worked but didn't know about the night shift because he's always there at 8.30 sharp. I was so surprised, I couldn't even say anything. If I were at his place, I wouldn't come for an English compulsory class, on time or even late, if I had to do these night duties. I felt as if the few efforts I had made paid off. I can now look back at this semester and be proud. Such a success story right in the first semester. This is what motivation can do!

Again, the positive experience leads T1 to feel happy and look towards the future with hope.

Last week, I told them that they would be given marks on their portfolio and therefore they should do their home assignments. $60 \%$ of students came with their homework. I felt very good but still there are students who are not doing it. How can I motivate them? 


\section{Celebrating Success}

T3 wrote:

On Friday, I walked into the class, confident and happy because I had an entire unit planned for four days. What a sense of achievement!

T3 seems to be celebrating her success and this is an important strategy. This may also suggest high work engagement on her part.

\section{CONCLUSION}

Teaching is a highly-demanding and at times, emotionally-draining profession. This study sheds light on how positive emotions shape behaviour and outcome of teachers, as analysed through their reflections. Hence the study brings together the fields of positive psychology and teacher education. The experiences of the three teachers reveal the paths each traversed as a result of their reflective inquiries. Teachers generally reflect on their problematic experiences (Janssen, de Hullu \& Tigelaar, 2008). This approach typically addresses gaps in skills but does not identify the personal strengths. As a pedagogical implication, teachers would be better served by redistributing their efforts and focussing on what is 'right' about their classrooms rather than what is 'wrong'. Also, the presentation of excerpts from teachers' reflections can be useful in teachertraining courses or in in-service training of teachers in order to provide opportunities for students and teachers to observe how reflections on positive experiences develop teachers' pedagogical practices.

\section{LIMITATIONS}

Since the present study focussed on three individual teachers, the results cannot be generalised. Secondly, the study explored teachers' perceptions of their pedagogical practices and functioning, and not their actual practices, hence the scope of the research is limited. Some researchers criticise such an approach: "It is our contention that research that examines only what university teachers say about their practice and does not directly observe what they do is at risk of telling half the story" (Kane, Sandretto \& Heath, 2002, pp. 177). However, it was not within the purpose or resources of this study to investigate the association between thought and behaviour by complementing the perceptions with observations of the teachers in actual teaching situations. Rather, the present study is thought of as providing a basis for further study that might include the thought-behaviour nexus. Hence, future research, perhaps involving classroom observation, is needed to make explicit the links between tertiary teachers' espoused theories and their teaching practice so that it could be better understood how university academics learn to teach, and, especially, so that novice teachers may benefit. 


\section{REFERENCES}

Chuang, S.C. (2007). Sadder but wiser or happier and smarter? A demonstration of judgment and decision making. The Journal of Psychology, 14 (1), pp 63-76.

Coetzee, S., \& Viviers, R. (2007). An overview of research on positive psychology in South Africa. South African Journal of Psychology, 37 (3), pp 470-490.

Fredrickson, B.L. (2001). The role of positive emotions in positive psychology: The broaden-and-build theory of positive emotions. American Psychologist, 56 (3), pp 218226.

Fredrickson, B.L. (2002). Positive emotions. In C.R. Snyder \& S.J. Lopez (Eds.), Handbook of positive psychology (pp 120-134). Oxford: Oxford University Press.

Hargreaves, A. (1997). Positive change for school success: The 1997 ASCD Yearbook. Alexandria, VA: Association for Supervision and Curriculum Development.

Hermans, H.J.M., \& Hermans-Jansen, E. (1995). Self-narratives: The construction of meaning in psychotherapy. New York: Guilford Press.

Howard, F. (2008). Managing stress or enhancing well-being? Positive psychology's contributions to clinical supervision. Australian Psychologist, 43 (2), pp 105-113.

Isen, A.M. (1987). Positive affect, cognitive processes, and social behavior. Advances in Experimental Social Psychology, 47, pp 1206-1217.

Isen, A.M., \& Daubman, K.A. (1984). The influence of affect on categorization. Journal of Personality and Social Psychology, 47, pp 1206-1217.

Isen, A.M., Johnson, M.M., Mertz, E., \& Robinson, G.F. (1985). The influence of positive affect on the unusualness of word associations. Journal of Personality and Social Psychology, 48, pp 1413-1426.

Isen, A.M., \& Nowicki, G.P. (1987). Positive affect facilitates creative problem-solving. Journal of Personality and Social Psychology, 52, pp 1122-1131.

Janssen, F. de Hullu, E., \& Tigelaar, D. (2008). Positive experiences as input for reflection by student teachers. Teachers and Teaching, 14 (2), pp 115-127.

Kane, R., Sandretto, S., \& Heath, C. (2002). Telling half the story: A critical review of research on the teaching beliefs and practices of university academics. Review of Educational Research, 72 (2), pp 177-228. 
Linley, P.A., Joseph, S., Harrington, S., \& Wood, A.M. (2006). Positive psychology: Past, present and (possible) future. The Journal of Positive Psychology, 1 (1), pp 3-16.

Lyons, N. (2006). Reflective engagement as professional development in the lives of university teachers. Teachers and Teaching: theory and practice, 12 (2), pp 151-168.

Pajares, M.F. (1992). Teachers' beliefs and educational research: Cleaning up a messy construct. Review of Educational Research, 62, pp 307-332.

Richardson, V. (1996). The role of attitudes and beliefs in learning to teach. In J. Sikula (Ed.), Handbook of research on teacher education (pp 102-119). New York: Simon \& Schuster.

Rimm-Kaufman, S.E., \& Sawyer, B.E. (2004). Primary-grade teachers' self-efficacy beliefs, attitudes toward teaching, and discipline and teaching practice priorities in relation to the "Responsive classroom" approach. The Elementary School Journal, 104 (4), pp 321-341.

Smedslund, J. (1997). The structure of psychological common sense. London: Lawrence Erlbaum.

Staw, B.M., Sutton, R.I., \& Pelled, L.H. (1994). Employee positive emotion and favorable outcomes at the workplace. Organization Science, 5 (1), pp 51-71.

Straus, A.L. (1987). Qualitative analysis for social scientists. New York: Cambridge University Press.

Sutton, R. E., \& Wheatley, K. F. (2003). Teachers' emotions and teaching: a review of the literature and directions for future research. Educational Psychology Review, 15 (4), pp 327-358.

van den Berg, R. (2002). Teachers' meanings regarding educational practice. Review of Educational Research, 72 (4), pp 577-625.

\section{Life at the Top}

Over the past decade or two, managing a large corporation has changed out of all recognition. That explains the emergence of the "CEO superman," such as Jack Welch of GE, Andrew Grove of Intel, or Sanford Weill of Citigroup. But organizations cannot rely on supermen to run them; the supply is both unpredictable and far too limited. Organizations survive only if they can be run by competent people who take their job seriously. That it takes genius today to be the boss of big organization clearly indicates that top management is in crisis.

P.F. Drucker: Managing in the Next Society, PP 289 